\title{
Cs AND Pu MIGRATION THROUGH ENGINEERED AND NATURAL BARRIERS *
}

\author{
G. Lujaniené ${ }^{\text {a }}$, S. Motiejūnas ${ }^{\text {b }}$, J. Šapolaite ${ }^{\text {a }}$, and Ž. Kamarauskas ${ }^{\text {a }}$

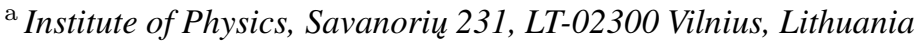 \\ E-mail: lujaniene@ar.fi.lt \\ ${ }^{\mathrm{b}}$ Radioactive Waste Management Agency, Algirdo 31, LT-03219 Vilnius, Lithuania
}

Received 20 June 2005

\begin{abstract}
Performance assessment of radioactive waste disposal requires modelling of long-term migration of radionuclides through the engineered barriers and the geological environment. The chemical complexity of sorption-desorption processes is usually reduced to integrated parameter distribution coefficients $\left(K_{\mathrm{d}}\right)$. There are a great number of publications on $K_{\mathrm{d}}$ determination, however, the existing data on $K_{\mathrm{d}}$ of radionuclides on different geological materials are for general understanding only and are not very useful for performance assessment since the changes of the geological conditions result in a variability of $K_{\mathrm{d}}$ values by two orders of magnitude. In order to obtain realistic sorption data sets for safety-relevant radionuclides present in a cement/concrete based repository some preliminary studies were carried out. The development of sorption database for the near-surface repository was started with measurements of cesium and plutonium $K_{\mathrm{d}}$ values. Samples of loam available at the Galilaukė site (Quaternary deposits) and Triassic clay from industrial Šaltiškiai quarry selected as a candidate for the engineered barrier of Lithuanian near-surface repository were taken for laboratory investigations. Several experiments were performed in order to determine the chemical composition of cement water which could originate from infiltration of precipitation and from contact of groundwater with concrete. More than 100 batch sorption experiments were conducted with two clay samples. Cs and $\mathrm{Pu} K_{\mathrm{d}}$ values were determined under a wide range of geochemical conditions. Changes in the geochemical conditions resulted in the variability of $\mathrm{Cs}$ and $\mathrm{Pu} K_{\mathrm{d}}$ values.
\end{abstract}

Keywords: $\mathrm{Cs}, \mathrm{Pu}$, distribution coefficients $\left(K_{\mathrm{d}}\right)$, clay, surface repository, radioactive waste

PACS: $28.41 . \mathrm{Kw}, 82.33 . \mathrm{z}$, 82.80.Ej, 82.80.Jp

\section{Introduction}

The fate and transport of dissolved contaminants in the geological environment to a great extent are determined by radionuclide interactions with mineral surfaces. The retardation of radionuclides depends on geochemical processes which include aqueous speciation, redox and interface reactions, precipitation and dissolution of minerals as well as colloids. Changes in geochemical conditions (mineral and solution composition, $\mathrm{pH}, \mathrm{Eh}$, and temperature) can considerably affect the behaviour of different radionuclides. To assess migration of radioactive contaminants in the repository environment it is essential to identify important geochemical processes affecting the contaminant transport.

The retardation and engineering extraction of cesium are difficult problems. For sorbing the radionuclides such as Cs, long time is required to reach steady

\footnotetext{
* The report presented at the 36th Lithuanian National Physics Conference, 16-18 June 2005, Vilnius, Lithuania.
}

state conditions and its sorption-desorption behaviour in clay minerals is complicated $[1,2]$.

Cesium is one of the most important artificial radionuclides that has been introduced into the environment through nuclear weapons testing and the nuclear accident in Chernobyl in 1986; its inventories in radioactive waste are significant as well. The half-life of ${ }^{137} \mathrm{Cs}$ is 30.2 years and it is obvious that its migration to human accessible environment must be limited for only a few decades. The long-term isolation must be demonstrated where releases of ${ }^{135} \mathrm{Cs}$ (half-life is $2.3 \cdot 10^{6}$ years) from the high-level radioactive wastes are possible in addition to ${ }^{137} \mathrm{Cs}$. Harmful effects of cesium on animate nature are evident taking into account its properties: unlimited solubility, potential mobility, and high bioavailability. Cs exists in the environment in +1 oxidation state, the formation of organic and inorganic complexes has negligible effect on cesium speciation, and the dominant aqueous species in groundwater is the uncomplexed $\mathrm{Cs}^{+}$ion. The sorption-desorption pro- 
cesses of radiocesium on various minerals have been the subject of many recent studies $[3,4]$. The selective adsorption of Cs by mica-like minerals, such as illite $\left\{\left(\mathrm{K}, \mathrm{H}_{3} \mathrm{O}\right)(\mathrm{Al}, \mathrm{Mg}, \mathrm{Fe})_{2}(\mathrm{Si}, \mathrm{Al})_{4} \mathrm{O}_{10}\left[(\mathrm{OH})_{2}, \mathrm{H}_{2} \mathrm{O}\right]\right\}$, has been attributed to the large ionic radius, uncomplexing nature, and especially to its low hydration energy. Although cations with similar charges and ionic radii are expected to compete with cesium, the sequence of sorption ability of alkali elements $\mathrm{Na}^{+}<$ $\mathrm{K}^{+}<\mathrm{Rb}^{+}<\mathrm{Cs}^{+}$is in good agreement with the sequence of effective ionic radii of alkali elements and the sequence of single ion hydration enthalpies of alkali elements [5]. In the clay mineral muscovite, a fixed negative charge arises primarily from isomorphic substitution of $\mathrm{Al}^{3+}$ for $\mathrm{Si}^{4+}$ in the tetrahedral sheet comprising the siloxane site. In illite mineral with composition very close to that of muscovite, isomorphic substitution of $\mathrm{Al}^{3+}$ for $\mathrm{Si}^{4+}$ and partly of $\mathrm{Fe}^{2+}$ and $\mathrm{Mg}^{2+}$ for $\mathrm{Al}^{3+}$ enhances the stability of the $\mathrm{Cs}^{+}$-siloxane surface complex. Strongly sorbed $\mathrm{Cs}^{+}$ on fraered edge sites (FES), external basalt sites, or within the interlayer exists as an inner-sphere, dehydrated surface complex, which is usually much more stable than outer-sphere complexes [6]. Cesium sorbed to outersphere complexes can be easily desorbed and is distinguished for higher mobility in the environment, while inner-sphere sorption complexes can limit the Cs transport and bioavailability. In smectites, the isomorphous substitution in both tetrahedral and octahedral layers generates weak negative charges of the sheets thus leading to the formation of a structural feature and resulting in wide ranges of cation exchange capacity, selectivity, and swelling properties. Water and cations $\left(\mathrm{H}^{+}, \mathrm{Na}^{+}, \mathrm{Ca}^{2+}, \mathrm{Mg}^{2+}\right)$ can easily penetrate into the smectite interlayer and participate in exchange processes and, for example, from a species like beidellite the sorbed cation can easily be ion-exchanged by the other cations. However, the existence of electrostatically stable sorption site for a cation with ionic size small enough to enter the hole was established for montmorillonite [7].

Plutonium comprises only small part of total activities even in spent fuel, however, the toxic effect of ${ }^{239} \mathrm{Pu}$ (half-life is 24400 years) will be dominant for thousands of years after the decay of short-lived fission products. Plutonium can exist in 4 oxidation states under the conditions and the $\mathrm{pH}$ typically present in the natural environment. Plutonium exhibits a complicated redox behaviour that permits transformation of one oxidation state into another. Under oxidizing conditions, $\mathrm{Pu}(\mathrm{IV}), \mathrm{Pu}(\mathrm{V})$, and $\mathrm{Pu}(\mathrm{VI})$ are common, whereas, un- der reducing conditions, $\mathrm{Pu}(\mathrm{III})$ and $\mathrm{Pu}(\mathrm{IV})$ would exist [8]. Dissolved plutonium forms the strong hydroxycarbonate-mixed ligand complexes, therefore, its adsorption and mobility can be strongly affected by these complex species. Under conditions of low $\mathrm{pH}$ and high concentrations of dissolved organic carbon, it appears that plutonium-organic complexes can control adsorption and mobility of plutonium in the environment. Plutonium can adsorb on different geological materials from low to extremely high affinities, with $K_{\mathrm{d}}$ values typically ranging over 4 orders of magnitude (from 11 to $330000 \mathrm{ml} / \mathrm{g}$ ) [9]. The changes in oxidation state of plutonium considerably affect its mobility in the environment. The environmental mobility of $\mathrm{Pu}(\mathrm{IV})$ is from 2 to 3 orders of magnitude lower than the mobility of $\mathrm{Pu}(\mathrm{V})$ or $\mathrm{Pu}(\mathrm{VI}) . \mathrm{Pu}(\mathrm{III})$ due to its negative potential at higher $\mathrm{pH}$ can be readily oxidized by water at even neutral $\mathrm{pH}$ levels $[10,11]$. Therefore, it is supposed that plutonium exists in $+4,+5$, and +6 oxidation states in natural environment at low $\mathrm{pH}$ values. Disproportionation reactions have negligible effect on the plutonium oxidation state in natural systems with typically low concentrations [11]. However, interactions with various minerals (e. g., goethite $(\alpha-\mathrm{FeOOH})$, manganite $\left(\mathrm{Mn}(\mathrm{III}) \mathrm{O}_{2} \mathrm{H}\right)$, hausmannite $\left(\mathrm{Mn}(\mathrm{II} / \mathrm{III})_{3} \mathrm{O}_{4}\right)$, pyrolusite $\left(\beta-\mathrm{Mn}(\mathrm{IV}) \mathrm{O}_{2}\right)$, and birnessite $\left(\delta-\mathrm{Mn}(\mathrm{IV}) \mathrm{O}_{2}\right)$ with different redox potentials can change the plutonium sorption characteristics by either oxidizing or reducing the sorbed species [12-16]. In addition, the interaction with the bacteria can cause changes in the oxidation state of plutonium under environmental conditions $[17,18]$. The published material provides much useful information on the mobility of plutonium, but some of these publications are contradictory, especially regarding the oxidation state and speciation of plutonium at low $\mathrm{pH}$ values, and also the data obtained from the experiments conducted without the determination of the oxidation state of plutonium. Thus, further studies related to the behaviour of plutonium in different environments under controlled oxidation state are required.

\section{Methods}

The chemical composition of groundwater and the cement water solutions was determined. Samples of the natural groundwater $(\mathrm{GW})$ from the well No 5 of the Galilauke site and the synthetic rain water (SRW) (filtered through the $0.45 \mu \mathrm{m}$ membrane filter) were put into contact with the solidified locally available Portland cement (from Akmenès cementas) to obtain the 
Table 1. Chemical composition of solutions used in sorption experiments.

\begin{tabular}{ccccc}
\hline & \multicolumn{4}{c}{ Type of solution } \\
\cline { 2 - 5 } & $\mathrm{GW}$ & GWCW & SRW & SRWCW \\
\hline $\mathrm{SO}_{4}^{2-}, \mathrm{mg} / 1$ & 94.76 & 109.52 & 1.22 & 2.90 \\
$\mathrm{NO}_{3}^{-}, \mathrm{mg} / 1$ & $<0.4$ & 2.16 & 0.71 & 4.40 \\
$\mathrm{Cl}^{-}, \mathrm{mg} / 1$ & 8.29 & 20.68 & 0.75 & 345.78 \\
$\mathrm{~F}^{-}, \mathrm{mg} / 1$ & 0.08 & 0.32 & - & 0.32 \\
$\mathrm{NH}_{4}^{+}, \mathrm{mg} / 1$ & 0.50 & 3.00 & 0.41 & 2.26 \\
$\mathrm{Na}^{+}, \mathrm{mg} / 1$ & 59.00 & 49.00 & 0.58 & 22.57 \\
$\mathrm{~K}^{+}, \mathrm{mg} / 1$ & 6.90 & 370.00 & 0.14 & 545.02 \\
$\mathrm{Ca}^{2+}, \mathrm{mg} / 1$ & 25.00 & 183.20 & 0.42 & 96.82 \\
$\mathrm{Mg}^{2+}, \mathrm{mg} / 1$ & 40.39 & 0.01 & - & 0.03 \\
$\mathrm{Al}^{3+}, \mathrm{mg} / 1$ & 0.018 & 0.01 & - & 0.64 \\
$\mathrm{Si}, \mathrm{mg} / 1$ & 3.26 & 0.24 & - & 0.50 \\
$\mathrm{pH}$ & 7.81 & 12.61 & 4.89 & 11.61 \\
$\mathrm{U}, \mathrm{mV}$ & -60.1 & -335.0 & 108.5 & -283.0 \\
$\chi, \mathrm{mS} / \mathrm{cm}$ & 1.09 & 8.04 & 0.23 & 2.15 \\
\hline
\end{tabular}

extracts of groundwater - cement water (GWCW) and synthetic rainwater - cement water (SRWCW) solutions (Table 1). The particles of different sizes of solidified cement were used in the experiments. The chemical composition of the extracts was determined by the atomic absorption spectrometry and the ion chromatography techniques (Table 1). The composition of rainwater was estimated taking into account the long-term studies performed in Lithuania [19].

The laboratory batch method was used for the determination of $K_{\mathrm{d}}$ values. The protocol of the standard method used at Pacific Northwest National Laboratory for measuring laboratory batch $K_{\mathrm{d}}$ values was applied [9].

The tests were performed under atmosphere conditions at $25{ }^{\circ} \mathrm{C}$. The sample was disaggregated by an ultrasonic method. The total concentration of cesium in solutions was $2.30 \cdot 10^{-10} \mathrm{~mol} / 1$ and the solutions were labeled by ${ }^{134} \mathrm{Cs}$. The ${ }^{134} \mathrm{Cs}$ activities were measured with an intrinsic germanium detector (resolution $1.9 \mathrm{keV} / 1.33 \mathrm{MeV}$ and relative efficiency $42 \%$ ). Measuring time varied according to sample activities. An efficiency calibration of the system was performed using calibration sources (prepared from a solution supplied by Amersham, UK) of different densities and geometry that were close to measured samples. Accuracy and precision of analysis were tested in intercomparison runs, organized by the Riso National Laboratory, Denmark. Precision of ${ }^{134} \mathrm{Cs}$ measurements by gamma spectrometry was $\leq 3 \%$. The sorption of cesium on centrifuge bottle walls was detected to be less than $2 \%$.

Plutonium for tracer experiments was prepared by the separation of plutonium isotopes from the highly contaminated Chernobyl soil. Three cycles of the ion exchange and the extraction chromatography were used to purify plutonium. The prepared plutonium tracer was standardized using ICP-MS and alpha spectrometry.

$\mathrm{Pu}(\mathrm{IV})$ was used in sorption experiments. The oxidation state purity of $\mathrm{Pu}(\mathrm{IV})$ stock solution was analyzed by solvent extraction at $\mathrm{pH} 0.5$ using $0.5 \mathrm{M}$ thenoyltrifluoroacetone (TTA) as extractant [20]. Typically $96 \pm 3 \%$ of the total plutonium was found in the tetravalent state. In addition, oxidation state analyses were preformed in the GW and the GWCW solution samples after 20 hours. The redox speciation of plutonium was studied using TTA and di(2ethylhexyl)orthophosphoric acid (HDEHP) as extractants [21,22].

To determine $K_{\mathrm{d}}$ values each clay sample was prepared by adding $1.0 \mathrm{~g}$ of studied clay to a pre-weighed, acid washed polypropylene centrifuge tube. The GW and GWCW solutions of different dilutions, the $\mathrm{pH}$ of which ranged from 5 to 13 , were passed through $0.45 \mu \mathrm{m}$ pore size filters. A $10 \mathrm{ml}$ aliquot of these solutions was added to the respective tubes. The samples were then placed on an end-over-end shaker and the solutions were changed every other day until the $\mathrm{pH}$ remained stable over the desirable range. The empty blank tubes containing no clay were also prepared to evaluate adsorption of the plutonium to the tube walls. From 1 to $12 \%$ of $\mathrm{Pu}(\mathrm{IV})$ was found adsorbed to the tube walls for samples containing geological materials. The initial concentration of $\mathrm{Pu}(\mathrm{IV})$ was adjusted by this fraction.

The blank and sample tubes are centrifuged for twenty minutes at $10,000 \mathrm{~g}$. After the $\mathrm{pH}$ remained stable for 48 hours ( $\pm 0.1 \mathrm{pH}$ units), $\mathrm{Pu}(\mathrm{IV})$ spike was added for a final concentration of $\sum \mathrm{Pu}=1.11$. $10^{-9} \mathrm{~mol} / \mathrm{l}$. Solids were separated from liquid by centrifugation after 10-day contact. Plutonium quantties in the solution and the geological material were determined after radiochemical separations based on the extraction chromatography. The UTEVA and TRU columns from Eichrom Industries were used and activities were measured by alpha spectrometry. ${ }^{242} \mathrm{Pu}$ was used as tracer in the separation procedure. $K_{\mathrm{d}}$ values of $\mathrm{Cs}$ and $\mathrm{Pu}$ were determined from three replicates.

\section{Results and discussion}

To obtain cesium $K_{\mathrm{d}}$ values for the natural clay based on soil material originated from the Galilauke site (Galilaukè clay) and smectite clay material (Šaltiškiai clay) selected as a candidate for the engineered 

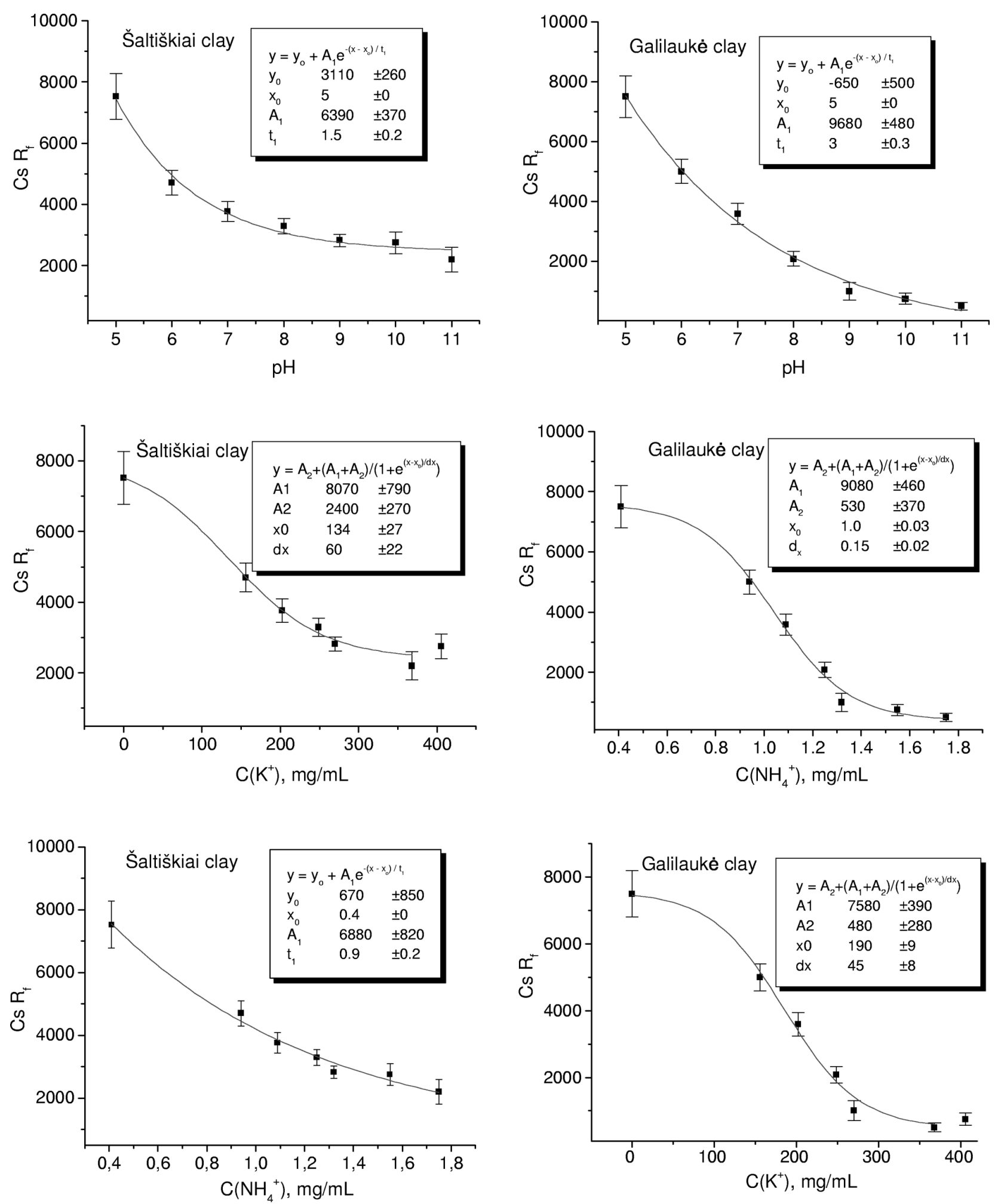

Fig. 1. Cs $R_{f}$ values variations depending on different chemical composition of rainwater - cement solutions. 
Table 2. Cesium and plutonium distribution coefficients.

\begin{tabular}{cccccc}
\hline & \multicolumn{3}{c}{ Distribution coefficients, $K_{\mathrm{d}}, \mathrm{ml} / \mathrm{g}$} \\
\cline { 2 - 3 } \cline { 5 - 6 } Type of used & \multicolumn{2}{c}{ Galilauke clay } & & \multicolumn{2}{c}{ Saltiškiai clay } \\
\cline { 2 - 3 } \cline { 5 - 6 } solution & $\mathrm{Cs}$ & $\mathrm{Pu}$ & & $\mathrm{Cs}$ & $\mathrm{Pu}$ \\
\hline SRW & $1500 \pm 110$ & $140000 \pm 11000$ & & $1600 \pm 100$ & $20000 \pm 1700$ \\
GW & $9700 \pm 900$ & $120000 \pm 9000$ & & $8400 \pm 800$ & $15000 \pm 1200$ \\
SRWCW & $1100 \pm 70$ & $140000 \pm 10000$ & & $1400 \pm 800$ & $20000 \pm 1600$ \\
GWCW & $450 \pm 30$ & $80000 \pm 6000$ & & $500 \pm 40$ & $21000 \pm 1700$ \\
\hline
\end{tabular}

barrier of the Lithuanian near-surface repository, SRW, GW, SRWCW, and GWCW solutions were used (Table 1). The average values obtained from three replicates are presented in Table 2. $K_{\mathrm{d}}$ values are in good agreement with ones presented in various publications and ranged from 10000 to $100 \mathrm{ml} / \mathrm{g}$. The highest values were detected for natural groundwater. The Šaltiškiai clay exhibited a retention capacity towards cesium. The low $K_{\mathrm{d}}$ values were expected under alkaline conditions ( $\mathrm{pH}$ 11-13), however, comparatively low $K_{\mathrm{d}}$ values determined in experiments using SRW indicated that acid rainwater can affect the cesium retention. Sorption as a function of $\mathrm{pH}$ and chemical composition of contact solutions was studied. It was supposed that the $\mathrm{pH}$ and the chemical composition of rain and groundwater can vary in natural conditions depending on their contact time with cement material and/or different dissolution. Two sorption experiments were conducted. These studies showed the decrease in $\mathrm{Cs} K_{\mathrm{d}}$ values with the increase in the $\mathrm{pH}$ of aqueous phase. The variation in $\mathrm{pH}$ values can affect the retention of cesium ions by clay minerals due to competition reactions and because of a partial dissolution of clay. The effect of $\mathrm{pH}$ on the sorption process is very well known, however, a certain degree of clay dissolution is possible and the stability of clay is a function of $\mathrm{pH}$ [23]. It should be noted that the stability of clay during the experiment was not controlled. Moreover, the degradation of cement results not only in the $\mathrm{pH}$ increase but also in the release of $\mathrm{K}^{+}, \mathrm{Na}^{+}, \mathrm{Ca}^{2+}$, $\mathrm{NH}_{4}^{+}$ions into solution. All of them can displace Cs from different sorption sites and affect a retardation of Cs. Retardation factors for unsaturated conditions were calculated using obtained $K_{\mathrm{d}}$ values and clay properties [24]. The retardation factor is the empirical parameter commonly used in transport models to describe the chemical interaction between the contaminant and geological materials. Depending on the conditions under which the contaminant moves and interacts with the geological material, the retardation factor can correlate with the distribution coefficient in different ways. Different formulations of the retardation factor have been proposed $[25,26]$. The retardation factor $\left(R_{f}\right)$ is the ratio of the pore-water velocity $\left(v_{\mathrm{p}}, \mathrm{cm} / \mathrm{h}\right)$ to the contaminant velocity $\left(v_{\mathrm{c}}, \mathrm{cm} / \mathrm{h}\right): R_{f}=v_{\mathrm{p}} / v_{\mathrm{c}}$. Retardation factors of $\mathrm{Cs}$ (for rainwater experiment) versus the $\mathrm{pH}$ values and the concentration of $\mathrm{K}^{+}, \mathrm{NH}_{4}^{+}$ions which are able to compete with Cs for FES are plotted in Fig. 1. The values of Cs $R_{f}$ decrease exponentially with an increase in the $\mathrm{pH}$ values and the concentration of $\mathrm{NH}_{4}^{+}$(for Šaltiškiai clay). In the other cases a more complicated decrease that corresponds to the sigmoidal (Boltzmann) fit was observed. Desorption experiments show that from 25 to $37 \%$ of reversibly sorbed cesium can be released to the surrounding solution. The released fraction increased in desorption experiments with samples in which the higher concentrations of $\mathrm{K}^{+}$ions were used in sorption experiments. It seems that $\mathrm{K}^{+}$ions can block the FES and in such a manner can reduce the portion of irreversibly sorbed cesium.

It is very well known that the chemical behaviour of plutonium in the environment is primarily defined by its oxidation state. Due to variations of the chemical properties for each oxidation state, the reactions of each oxidation state should be taken into account in conceptual models. Plutonium is able to exist in five different oxidation states as the oxy/hydroxy ions $\mathrm{Pu}(\mathrm{III})^{3+}$, $\mathrm{Pu}(\mathrm{IV})^{4+}, \mathrm{Pu}(\mathrm{V}) \mathrm{O}_{2}^{+}, \mathrm{Pu}(\mathrm{VI}) \mathrm{O}_{2}^{2+}$, and $\mathrm{Pu}(\mathrm{VII}) \mathrm{O}_{4}^{-1}$. $\mathrm{PuO}_{4}^{-}$is not considered to be a stable species in the natural environment. In moderate $\mathrm{pH}$ or oxic groundwater, $\mathrm{Pu}(\mathrm{III})$ is rapidly oxidized to $\mathrm{Pu}(\mathrm{IV})$ [11].

Plutonium $\mathrm{Pu}(\mathrm{IV}), \mathrm{Pu}(\mathrm{V}), \mathrm{Pu}(\mathrm{VI})$ oxidation state analysis was performed on the aqueous phase of the lowest pH GWCW solution used in the sorption experiments and the GW sample from Galilauke site. Our preliminary results of plutonium redox speciation are presented in Fig. 2. It can be seen that $\mathrm{Pu}(\mathrm{IV})$ was still the dominant species in the GWCW solution $(\mathrm{pH} 12.6)$ and there was no evidence of $\mathrm{Pu}(\mathrm{VI})$ in the GWCW and in the GW samples after twenty hours. About $50 \%$ of the $\mathrm{Pu}(\mathrm{VI})$ spiked was found in the pentavalent oxidation state in the GW samples. Although thermodynamic calculations indicate the $\mathrm{Pu}(\mathrm{V})$ 

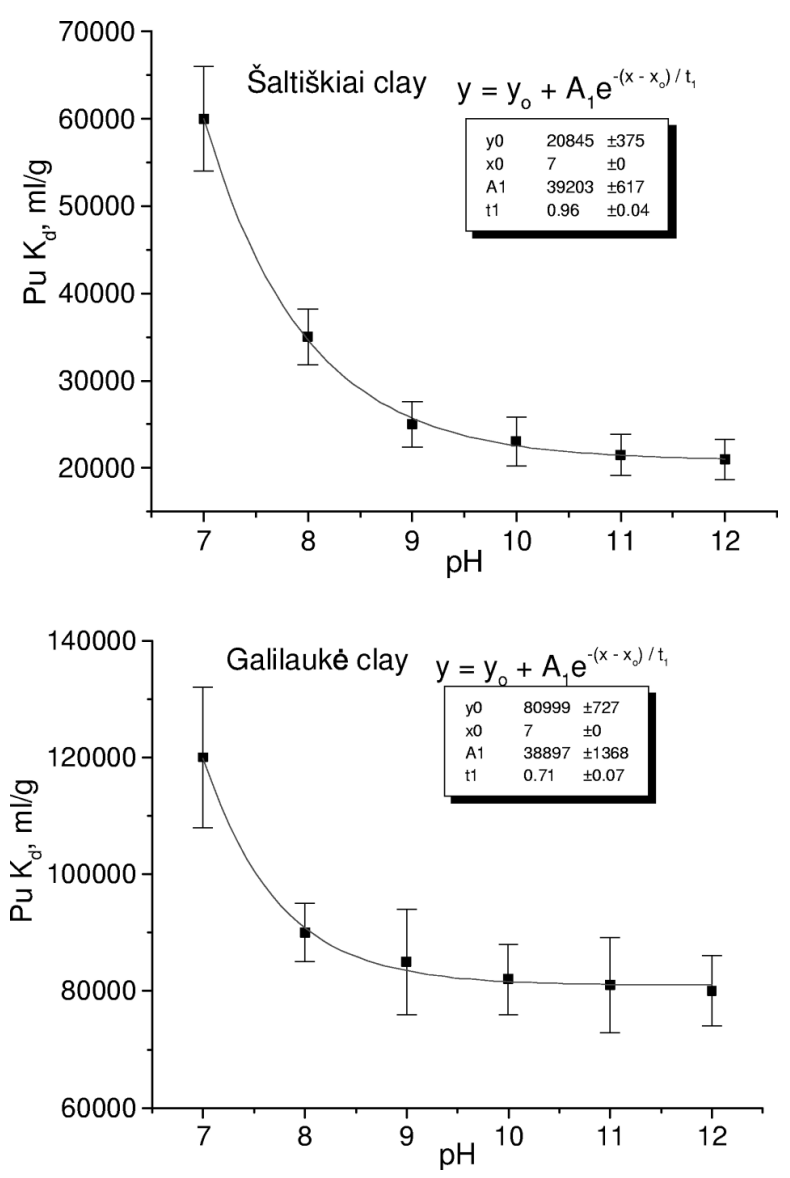

Fig. 2. Plutonium $K_{\mathrm{d}}$ values depending on $\mathrm{pH}$ in groundwater cement solutions.

as the most stable species under environmental conditions [11], this result is rather unexpected. It can possibly be attributed to the plutonium oxidation by pyrolusite $\left(\beta-\mathrm{Mn}(\mathrm{IV}) \mathrm{O}_{2}\right)$ and/or birnessite $\left(\delta\right.$ - $\left.\mathrm{Mn}(\mathrm{IV}) \mathrm{O}_{2}\right)$ colloids usually present in solutions [15,27]. $\mathrm{MnO}_{2}$ colloids could be present in the GWCW solutions since they were prepared using the same groundwater. Although a decrease in the concentration of hydrogen ion favours the oxidation reaction since more binding sites on the negatively charged surface of manganese dioxide are available, but increasing the $\mathrm{pH}$ values also enhances the influence of the hydrolysis reactions of $\mathrm{Pu}(\mathrm{IV})$ and the formation of $\mathrm{Pu}(\mathrm{OH})_{4}^{0}$ stabilizes the tetravalent state. The negligible amount of $\mathrm{Pu}(\mathrm{IV})$ hydroxide polymers found in the both studied solutions can hardly be attributed to the formation of intrinsic colloids because of the low concentration of plutonium $\left(\sum \mathrm{Pu}=1.11 \cdot 10^{-9} \mathrm{~mol} / \mathrm{l}\right)$ used in the sorption experiments. However, this result can be explained by association of $\mathrm{Pu}(\mathrm{IV})$ with various pseudocolloids commonly present in natural waters. According to our studies and published data $[28,29]$ the possible $\mathrm{Pu}$ species in the aqueous phases were estimated as follows: $\mathrm{Pu}(\mathrm{OH})_{4}^{0}$,

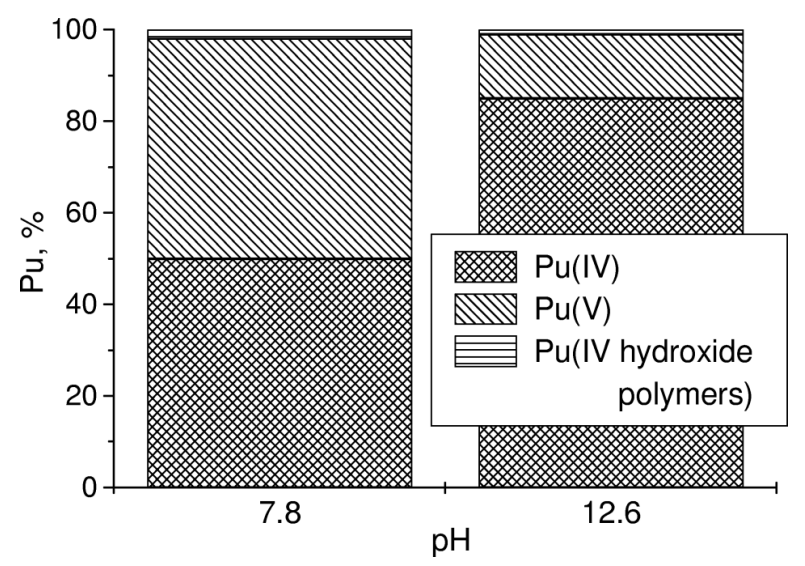

Fig. 3. Redox speciation of $\mathrm{Pu}$ in groundwater ( $\mathrm{pH} 7.8$ ) and groundwater - cement water ( $\mathrm{pH} 12.6)$ after 20 hours.

$\mathrm{PuO}_{2}^{+}$, and $\mathrm{PuCO}_{3}^{+}$. Differences in the $\mathrm{Pu}$ speciation and changes in the chemical composition of aqueous phase resulted in the variation of $\mathrm{Pu} K_{\mathrm{d}}$ values (Fig. 3). The exponential decrease in the $\mathrm{Pu} K_{\mathrm{d}}$ values with the increase in the $\mathrm{pH}$ of aqueous phase was found for both clays (Fig. 3). Strong sorption (higher $K_{\mathrm{d}}$ values) of $\mathrm{Pu}$ to the Galilauke clay can possibly be attributed to the mineralogical composition of clays.

\section{Conclusions}

Cs $K_{\mathrm{d}}$ values ranged from 10000 to $100 \mathrm{ml} / \mathrm{g}$. The retention capability of the clays was significantly reduced due to the impact of alkaline Portland cement. The highest values were detected for natural groundwater. $K_{\mathrm{d}}$ values of Pu ranged from 15000 to $21000 \mathrm{ml} / \mathrm{g}$. The exponential decrease in the $\mathrm{Pu} K_{\mathrm{d}}$ values with the increase in the $\mathrm{pH}$ of aqueous phase was found for both clays. Results of determination of plutonium redox speciation indicated that $\mathrm{Pu}(\mathrm{IV})$ was still the dominant species in the GWCW solution ( $\mathrm{pH} 12.6)$ and there was no evidence of $\mathrm{Pu}(\mathrm{VI})$ in the GWCW and in the GW samples after twenty hours. About $50 \%$ of the $\mathrm{Pu}(\mathrm{VI})$ spiked was found in the pentavalent oxidation state in the GW samples.

\section{Acknowledgements}

This study was supported by the Radioactive Waste Management Agency and the Lithuanian State Science and Studies Foundation project No C-19/2003. In addition, we would like to express our gratitude to $\mathrm{Dr}$ D. Jasinevičienè and Dr D. Valiulis for assistance in the performance of measurements. 


\section{References}

[1] T. Kozaki, H. Sato, S. Sato, and H. Ohashi, Diffusion mechanism of caesium in compacted montmorillonite, Engin. Geology, 54, 223-230 (1999).

[2] J.L. Krumhansl, P.V. Brady, and H.L. Anderson, Reactive barriers for ${ }^{137} \mathrm{Cs}$ retention, J. Contam. Hydrol. 47, 233-240 (2001).

[3] Y. Kim and R.J. Kirkpatrick, ${ }^{23} \mathrm{Na}$ and ${ }^{133} \mathrm{Cs}$ NMR study of cation adsorption on mineral surfaces: Local environments, dynamics, and effects of mixed cations, Geochim. Cosmochim. Acta 61, 5199-5208 (1997).

[4] T. Onuki, Sorption characteristics of cesium on sandy soils and their components, Radiochim. Acta 64, 1521 (1994).

[5] D.T. Richens, The Chemistry of Aqua Ions, Syntheses, Structure and Reactivity (John Wiley \& sons, Chichester, 1997), Appendices 2 and 3, p. 5.

[6] K.M. Kemner, D.B. Hunter, P.M. Bertsch, J.P. Kirkland, and W.T. Elam, Determination of site-specific binding environments of surface sorbed cesium on clay minerals by Cs-EXAFS, J. Phys. IV France 7, 777-779 (1997).

[7] Y. Onodera, T. Iwasaki, T. Ebina, H. Hayashi, K. Torii, A. Chatterjee, and H. Mimura, Effect of layer charge on fixation of cesium ions in smectites, J. Contaminant Hydrology 35, 131-140 (1998).

[8] The Chemistry of the Actinide Elements, 2nd ed., Vols. 1 and 2, eds. J.J. Katz, G.T. Seaborg, and L.R. Morss (Chapman and Hall, New York, 1986); The Chemistry of Actinides, Vols. 1-3, ed. B.F. Myasoedov (Mir, Moscow, 1997) [in Russian].

[9] Understanding Variation in Partition Coefficients, $K_{\mathrm{d}}$ values, United States Office of Air and Radiation EPA Report 402-R-99-004A (1999).

[10] J.D. Farr, R.K. Schulze, and B.D. Honeymann, Aqueous $\mathrm{Pu}(\mathrm{IV})$ sorption on brucite, Radiochim. Acta 88, 675-679 (2000).

[11] G.R. Choppin, A.H. Bond, and P.M. Hromadka, Redox speciation of plutonium, J. Radioanal. Nucl. Chem. 219(2), 203-210 (1997).

[12] A.L. Sanchez, J.W. Murray, and T.H. Sibley, The adsorption of plutonium IV and V on goethite, Geochim. Cosmochim. Acta 49, 2297-2307 (1985).

[13] W.L. Keeney-Kennicutt and J.W. Morse, The redox chemistry of $\mathrm{PuO}^{2+}$ interaction with common mineral surfaces in dilute solutions and seawater, Geochim. Cosmochim. Acta 49, 2577-2588 (1985).

[14] M.C. Duff, D.B. Hunter, I.R. Triay, P.M. Bertsch, D.T. Reed, S.R. Sutton, G. Shea-McCarthy, J. Kitten, P. Eng, S.J. Chipera, and D.T. Vaniman, Mineral associations and average oxidation states of sorbed $\mathrm{Pu}$ on tuff, Environ. Sci. Tech. 33, 2163-2169 (1999).

[15] A. Morgenstern and G.R. Choppin, Kinetics of the oxidation of $\mathrm{Pu}(\mathrm{IV})$ by manganese oxide, Radiochim. Acta 90(2), 69-74 (2002).
[16] G.R. Choppin and A. Morgenstern, in: Plutonium in the Environment, ed. A. Kudo (Elsevier Science, 2001) pp. 91-104.

[17] B.A. Strietelmeier, R.J. Sebring, J.B. Gillow, C.J. Dodge, M.E. Pansoy-Hjelvik, S.M. Kraus, P.A. Leonard, I.R. Triay, A.J. Francis, and H.W. Papenguth, Plutonium interaction with a bacterial strain isolated from the waste isolation pilot plant (WIPP) environment, American Chemical Society, Division of Environmental Chemistry, Preprints of Extended Abstracts 36(2) (1996).

[18] P.J. Panak and H. Nitsche, Interaction of aerobic soil bacteria with plutonium(VI), Radiochim. Acta 89, 499-504 (2001).

[19] http://aaa.am.lt

[20] P.A. Berthard and G.R. Choppin, Separation of actinides in different oxidation states by solvent extraction, Radiochim. Acta 31, 115 (1985).

[21] M.P. Neu, D.C. Hoffman, K.E. Roberts, H. Nitsche, and R.J. Silva, Comparison of chemical extractions and laser photoacoustic spectroscopy for the determination of plutonium species in near-neutral carbonate solutions, Radiochim. Acta 66, 265-272 (1994).

[22] H. Nitsche, S.C. Lee, and R.C. Gatti, Determination of plutonium oxidation states at trace levels pertinent to nuclear waste disposal, J. Radioanal. Nucl. Chem. 124(1), 171-185 (1988).

[23] C. Poinssot, B. Baeyens, and M.H. Bradburry, Experimental and modeling studies of caesium sorption on illite, Geochim. Cosmochim. Acta 63(19/20), 32173227 (1999).

[24] Characterisation of Materials Suitable for Engineering Barriers of Near Surface Repository of Radioactive Waste (Ecofirma, 2004) [in Lithuanian].

[25] H. Bouwer, Simple derivation of the retardation equation and application to preferential flow and macrodispersion, Ground Water 29, 41-46 (1991).

[26] G. Whelan, J.P. McDonald, and C. Sato, Multimedia Environmental Pollutant Assessment System (MEPAS): Groundwater Pathway Formulations, report PNNL10907 (Pacific Northwest National Laboratory, Richland, Washington 1996).

[27] A.B. Krasanova, St.N. Kalmykov, N.S. Shcherbina, A.P. Novikov, and S.B. Clark, Sorption of plutonium and neptunium onto colloidal $\mathrm{Fe}$ - and $\mathrm{Mn}$ oxides, in: Advances in Nuclear and Radiochemistry, eds. S.M. Qaim and H.H. Coenen, extended abstracts of the 6th International Conference on Nuclear and Radiochemistry (NRC-6), 29.08. - 03.09.2004, Aachen, Schriften der Forschungszentrums Jülich, Reihe Allgemeines und Interdisziplinäres 3, ISSN 1433-5565, ISBN 3-89336-362-9 (2004) pp. 89-91.

[28] J.M. Delany and S.R. Lundeen, The LLNL Thermochemical Database, Lawrence Livermore National Laboratory Report UCRL-21658 (1990), p. 150. 
[29] D. Langmuir, Aqueous Environmental Chemistry (Prentice Hall, Upper Saddle River, New Jersey, 1997), pp. 486-547.

\title{
Cs IR Pu MIGRACIJA PRO DIRBTINIUS IR GAMTINIUS BARJERUS
}

\author{
G. Lujanienè ${ }^{a}$, S. Motiejūnas ${ }^{b}$, J. Šapolaitè ${ }^{a}$, Ž. Kamarauskas ${ }^{\text {a }}$ \\ ${ }^{\text {a }}$ Fizikos institutas, Vilnius, Lietuva \\ ${ }^{\mathrm{b}}$ Radioaktyviuju atlieku tvarkymo agentūra, Vilnius, Lietuva
}

\section{Santrauka}

Analizuojant radioaktyviuju atlieku tvarkymo saugą, reikalingas ilgalaikis radionuklidu migracijos pro dirbtinius barjerus bei geologinés aplinkos modeliavimas. Sudetingu cheminiu gertiesatvirkštinès gerties vyksmu aprašymas dažniausiai supaprastinamas panaudojant integruotą parametrą - pasiskirstymo koeficienta $\left(K_{\mathrm{d}}\right)$. Daugelyje duomenu baziu pateikiama informacija apie radionuklidu $K_{\mathrm{d}}$ vertes skirtingose geologinèse aplinkose. Tačiau ta informacija paprastai būna labai bendro pobūdžio ir mažai tinka saugos analizei, nes, kintant geologinėms sąlygoms, $K_{\mathrm{d}}$ vertès dažnai pakinta net dviem eilemmis. Siekiant nustatyti realius aktualiụ radiacinès saugos požiūriu radionuklidụ gerties betono saugyk- loje parametrus, preliminariai tirta $\mathrm{Cs}$ ir Pu migracija. Pradètas tu elementu gerties duomenu bazès kūrimas. Laboratoriniams tyrimams buvo paimti molių, parinktu paviršinès saugyklos Lietuvoje dirbtiniams barjerams, pavyzdžiai iš Galilaukès aikštelès (moreninis priemolis) ir pramoninio Šaltiškių karjero (triaso molis). Buvo atlikta keletas eksperimentu, siekiant nustatyti betono vandens, atsirandančio krituliu prasiskverbimo ir gruntinio vandens sąlyčio su betonu atvejais, cheminę sudètį. Atlikta daugiau nei 100 gerties eksperimentų, naudojant dviejų molių pavyzdžius. Cs ir Pu $K_{\mathrm{d}}$ vertès buvo nustatytos plačiame geocheminiu sąlygu intervale. Geocheminių sąlygų pokyčiai įtakojo $\mathrm{Cs}$ ir $\mathrm{Pu} K_{\mathrm{d}}$ verčių kintamumą. 